DOI 10.18551/rjoas.2019-08.35

\title{
IDENTIFICATION OF ANISAKID NEMATODE L3 LARVAE INFECTION ON SKIPJACK TUNA (KATSUWONUS PELAMIS L.) FROM KUPANG WATERS, EAST NUSA TENGGARA OF INDONESIA
}

\author{
Haryadi Linda ${ }^{1,4}$, Suprayitno Eddy ${ }^{2}$, Aulanni'am Aulanni'am ${ }^{3}$, Amin Mohamad $^{5}$, \\ Hariati Anik Martinah ${ }^{2 *}$ \\ ${ }^{1}$ Doctoral Program, Faculty of Fisheries and Marine Sciences, University of Brawijaya, \\ Malang, Indonesia \\ ${ }^{2}$ Faculty of Fisheries and Marine Sciences, University of Brawijaya, Malang, Indonesia \\ ${ }^{3}$ Department of Chemistry, Faculty of Mathematics and Natural Sciences, \\ University of Brawijaya, Malang, Indonesia \\ ${ }^{4}$ Fish Quarantine and Inspection Agency Kupang, Ministry of Marine Affairs and Fisheries \\ of Republic of Indonesia, Kupang, Indonesia \\ ${ }^{5}$ Department of Biology, Faculty of Mathematics and Sciences, University of Negeri Malang, \\ Malang, Indonesia \\ *E-mail: a hariati@ub.ac.id
}

\begin{abstract}
The larvae of Anisakis were living parasites and made marine mammals, birds and reptiles the definitive host. Identification of Anisakis larvae using morphological observation methods will be difficult, especially if there are only a few samples that can be identified. PCR is an identification method using DNA from a small sample quantity and can provide DNA sequence samples. This study aimed to determine the type and infection level of Anisakis sp. at skipjack tuna (Katsuwonus pelamis) from the Oeba Fish Auction (TPI) Kupang City morphologically and molecularly. Morphological analysis results of 30 Anisakis larvae showed the body parts of Anisakis larvae, namely the head, digestive tract, and tail. The infection of Anisakis nematodes in skipjack tuna found five individual nematodes in muscle tissue, 59 individuals in stomach tissue, and 1991 individuals in internal organs. Alignment results between isolates At1 and At2 against isolates $A$. typica comparing (outgroup), isolate At1 and At2 have high homologs. Based on the results of the study concluded that the type I Anisakis isolated from skipjack tuna (Savu Sea) was Anisakis typica.
\end{abstract}

\section{KEY WORDS}

Cetacean, dolphin, molecular, savu, whale.

Nematodes from the Anisakidae family are living parasites and make marine mammals, birds and reptiles a definitive host. Although the life cycle of this family is unclear, it is known that marine fish can act as intermediaries, paratenic hosts or definitive. Nematode Anisakis Djuardin, 1845 (Mladineo, Šimat, Miletić, Beck, \& Poljak, 2012), generally inhabits the digestive tract of aquatic vertebrates, where euphausiid crustaceans act as intermediate hosts, fish and cephalopods as paratenic, and cetaceans as final hosts. Some Anisakis species, such as Anisakis simplex and Anisakis pegriffii, are known to cause clinically significant disease in humans (Zhang et al., 2007).

Anisakis spp uses fish or aquatic invertebrates such as squid and shrimp as intermediary hosts. Anisakis larval stages in intermediate hosts are called L3 larvae (Sakanari \& Mckerrow, 1989) and (Nagasawa \& Moravec, 1995). Anisakis spp is commonly found living on the intestinal wall, liver and muscle of fish flesh and can cause pathological effects on fish (Yoshinaga, Kinami, Hall, \& Ogawa, 2006); (Hassan, Mohamed, \& Osman, 2013) (Koinari, Karl, Elliot, Ryan, \& Lymbery, 2013); (Anshary, Sriwulan, Freeman, \& Ogawa, 2014); (Palm et al., 2017); and (Setyobudi et al., 2019).

Specific identification of nematode larvae using morphological observation methods will be difficult, especially if there is only a small amount to identify. One way of identification, to overcome this, is the Polymerase Chain Reaction (PCR). The PCR method enables the 
identification process using DNA from a small quantity of material (nanograms to picograms) and provides a target DNA sequence (X. Zhu, Gasser, Podolska, \& Chilton, 1998). The results have shown that Internal Transcribe Spacers (ITS-1 and ITS-2) from ribosomal nuclear DNA (rDNA) provide genetic markers for identification of adult Anisacidae, including A. simplex, Hysterothylacium aduncum and Contracaecum rudolphii (XQ Zhu et al., 2002 ). Identification of Anisakis nematodes requires accuracy at the life cycle stage and each host center. It aims to understand Anisakis ecology and epidemiology, diagnosis, and key components of disease control and control (Cheng, 1982).

Therefore, the results of adult Anisakis sequencing function as a reference to identify the larval stage. The PCR mutation scanning process is combined with a selective sequence of ITS-1 and/or ITS-2. This process provides a powerful approach to identifying and differentiating Anisakis nematodes (at any stage of development). This identification process aims to diagnostic or taxonomy, explore the genetic composition of Anisakis larvae populations, and to investigate their ecology (X. Q. Zhu et al., 2007).

Molecular identification results by Palm, Damriyasa, Linda, \& Oka (2008) and Anshary et al. (2014) found $A$. typica species as the dominant species in the waters of Bali and the Makassar Strait. Both of these sea waters are close to the waters of East Nusa Tenggara. The study of $A$. typica in these two waters are inseparable from the life pattern of Anisakis nematodes, the distribution of skipjack tuna and mackerel tuna, and the migration patterns of several marine mammals as parentic hosts.

In this study, we want to develop and apply diagnoses based on molecular DNA bonds using ITS (Internal Transcribed Spacer) analysis. This study wants to prove the most dominant species found in fish samples, assuming $A$. typica is the species most often found in Indonesian waters. Fish sampling locations are Kupang waters, East Nusa Tenggara Province, Indonesia. This research is also based on the existence of reports of human cases infected with Anisakis nematodes. It needs to be investigated about the protein profile that is thought to be an allergen in humans. This study aimed to determine the type and level of Anisakis sp. infection on skipjack tuna (Katsuwonus pelamis) from the Oeba Fish Auction Place (TPI) of Kupang City morphologically and molecularly.

\section{MATERIALS AND METHODS OF RESEARCH}

Anisakis nematodes collected from skipjack tuna (Katsuwonus pelamis) which purchased from a fish auction place in the city of Kupang. Nematode larvae collected from the surface of the internal cavity and organs (liver, intestine, stomach, and gonads). The fresh nematodes washed several times using sterile water then with $0.9 \% \mathrm{NaCl}$ solution, then with pure water and finally with a $0.9 \% \mathrm{NaCl}$ solution. Furthermore, nematode larvae stored in $0.9 \% \mathrm{NaCl}$ solution at $-20{ }^{\circ} \mathrm{C}$ for protein extraction and partly in $70 \%$ ethanol at $4{ }^{\circ} \mathrm{C}$ for DNA extraction.

The morphological identification process refers to J. Grabda (1991). Anisakis L3 larvae purified using glycerin-phenol-lactic acid distilled water solution (2: 1: 1: 1). Morphological characteristics measured were body width, esophageal length, ventricular length, tail length, body length/body width, body length/esophageal length, body length/ventricular length, and body length/tail length (Setyobudi, Jeon, Lee, Seong, \& Kim, 2011). Nematodes observed with microscope (Axio Lab.A1 Zeiss).

The DNA extraction was modified from D 'Amelio et al. (2000). The nematodes rinsed with PBS and put in a $1.5 \mathrm{~mL}$ microtube. Then added with $200 \mathrm{~mL}$ extract buffer $(50 \mathrm{mM}$ TrisCl pH 8, $100 \mathrm{mMNaCL}, 5 \mathrm{mM}$ EDTA, $10 \%$ SDS, $10 \mathrm{mg} / \mathrm{mL}$ Proteinase $\mathrm{K}$ ). After that, it is homogenized and incubated in a water bath at $56^{\circ} \mathrm{C}$ for 2 hours. Then, added with $125 \mathrm{~mL}$ of $5 \mathrm{M} \mathrm{NaCl}$ and stirred with vortex for $10 \mathrm{sec}$ and centrifuged at 13,000 rpm for $5 \mathrm{~min}$. A total of $200 \mathrm{~mL} \mathrm{PCl} \mathrm{(25:24:1)} \mathrm{added} \mathrm{in} \mathrm{the} \mathrm{supernatant,} \mathrm{then} \mathrm{centrifuged} \mathrm{at} \mathrm{13,000} \mathrm{rpm} \mathrm{for} 10$ min. This centrifugation repeated with the addition of $200 \mathrm{~mL} \mathrm{Cl}$ (24: 1). The supernatant added with $500 \mathrm{~mL}$ absolute ethanol, then incubated for 1 hour at $-20^{\circ} \mathrm{C}$. The sample centrifuged for $10 \mathrm{~min}$ at $13,000 \mathrm{rpm}, 4^{\circ} \mathrm{C}$. After that, Pellets added with $500 \mathrm{~mL}$ of $70 \%$ ethanol then centrifuged for $5 \mathrm{~min}$ at $13,000 \mathrm{rpm} 4^{\circ} \mathrm{C}$. The pellet dried at $55^{\circ} \mathrm{C}$. Then $50 \mathrm{~mL}$ 
of TE buffer pH 7.6 added to the tube. The isolated DNA PCR amplified using ITS (ITS 1.58S rDNA and ITS 2), primers NC5 (forward; 5'-GTAGGTGAACCTGCGGAAGATCATT-3') and NC2 (reverse: 5' TTAGTTTCTTTTCCTCCGCT-3'). PCR program as many as 30 cycles at a temperature of $95^{\circ} \mathrm{C}$ for $15 \mathrm{~min}$ (predenaturation), $95^{\circ} \mathrm{C}$ for $1 \mathrm{~min}$ (denaturation), $55^{\circ} \mathrm{C}$ for 1 min (annealing), $72^{\circ} \mathrm{C}$ for $1 \mathrm{~min}$ (extension) and $72^{\circ} \mathrm{C}$ for $5 \mathrm{~min}$ (post extension). The reaction mixture for PCR includes PCR Mix $12.5 \mu \mathrm{L}$, ddH2O $8.5 \mu \mathrm{L}$, Primary Forward $1 \mu \mathrm{L}$, Primary Reverse $1 \mu \mathrm{L}$, DNA sample $2 \mu \mathrm{L}$.

\section{RESULTS OF STUDY}

Morphological Characters and Infection Rates of $A$. typica in Skipjack Tuna (K. pelamis). Anisacid larvae collected from 30 skipjack tuna (K. pelamis from NTT waters). The larvae were white, attached to the infected part, membranes wrapped with different distribution and intensity of infection. Internal organs (especially the stomach) are the organs with the highest infection rates. Morphological analysis was carried out on 30 individual larvae taken randomly, showing that the body parts of Anisacid larvae, namely the head, digestive tract, and tail. Part $A$ is the anterior end or head to describe the nematodes having three lips around the mouth and tooth on the top of the head (larvae). Part B is part of the ventricles or digestive tract, which consists of the esophagus, ventricles, and intestines. Part $B$ is an essential part because it used as a basis for identification of nematodes at the genus level. Part $\mathrm{C}$ is the posterior end or tail consisting of the anal glands, anus, and mucus (Figure 1).

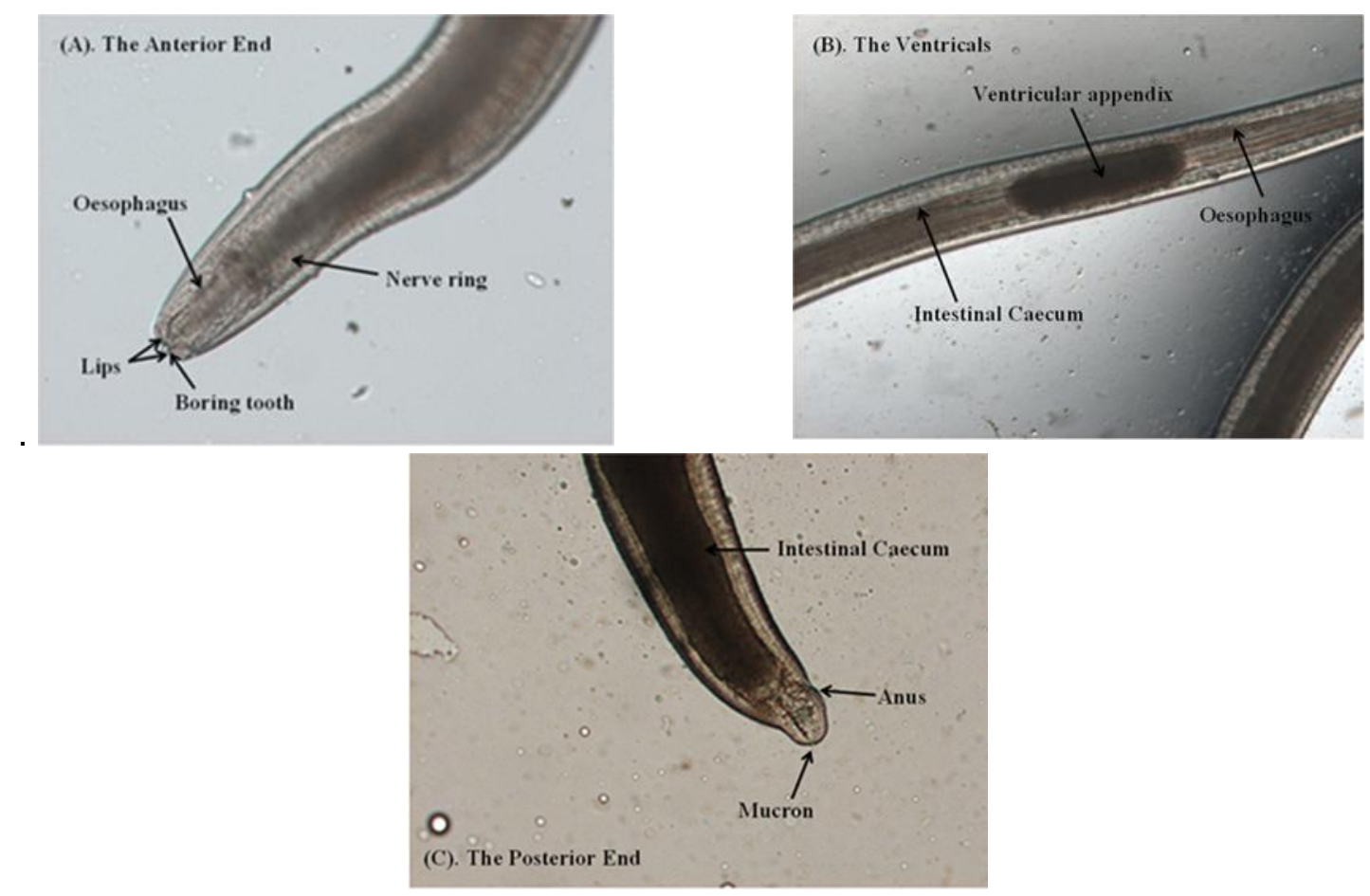

Figure 1 - Morphology of Anisakis Nematode. A). Anterior; B). Ventriculus; and C). Posterior

A total of 30 skipjack tuna, found five individuals nematodes in muscle tissue, 59 individuals nematodes in stomach tissue, and 1991 individuals nematodes in internal organs. Morphologically, the total body length is between $7.27-14.42 \mathrm{~mm}$, ventricular length 0.02 $0.08 \mathrm{~mm}$, mucron length 0.001-0.012 mm. Morphological characters were presented in Table 1.

The parasitic A. typica found on the inner surface of the body cavity and also found in muscles. However, the highest infection intensity of the parasite A. typica found in internal organs (stomach, liver, and intestine) (Palm et al., 2008). Morphologically the total body length is between $9-15 \mathrm{~mm}$, ventricular length $0.02-0.07 \mathrm{~mm}$, mucron length $0.02-0.03 \mathrm{~mm}$ 
(Quiazon, Yoshinaga, Santos, \& Ogawa, 2009). The size of the ventricular length is one of the important parameters in identifying Anisakis spp. morphologically. The use of ventricular display in identifying Anisakis species has been applied to Anisakis simplex (ss) and $A$. Pegreffii. Anshary (2011) also confirmed that Anisakis type I is characterized by the presence of boring tooth at the anterior end and the mucron at the posterior end.

Table 1 - Morphological characters of $A$. typica isolation from skipjack tuna (K. pelamis) from NTT waters*

\begin{tabular}{ccc}
\hline Morphological Characters & Size Range $(\mathrm{mm})$ & Average Size, (Mean \pm SD) $(\mathrm{mm})$ \\
\hline Maximum Length & $7.27-14.42$ & $11.53 \pm 1.83$ \\
Maximum Width & $0.20-0.48$ & $0,33 \pm 0.07$ \\
Esophagus Length & $0.01-0.80$ & $0.09 \pm 0.15$ \\
Ventriculus Length & $0.02-0.08$ & $0.04 \pm 0.01$ \\
Ventricular width & $0.01-0.02$ & $0.01 \pm 0.003$ \\
Mucron Length & $0.001-0.012$ & $0.003 \pm 0.002$ \\
\hline
\end{tabular}

*The number of larval samples: 40.

A. typica was commonly found in tropical fish species. A. typica was reportedly identified from the waters of the Southwest Atlantic, West and East Atlantic, the Mediterranean Sea, the Central Pacific. Latest data from IndoPacific waters, and free-living on bottlenose dolphins (Tursiops aduncus) from the Hurghada coastline in the northern Red Sea, Egypt (Palm et al., 2017).

Previous studies also reported that most Anisakis larvae that infect fish in Indonesian waters were identified as A. typica (Anshary et al., 2014 and Palm et al., 2017). Anisakis typica populations have been genetically detected over a wide geographical range, extending from 30 southern latitudes to 35 northern latitudes in warm and tropical climates (Simonetta Mattiucci \& Nascetti, 2008). Whales (Kogia breviceps and Peponochephala electra) and dolphins (Sotalia guieanensis, Sotalia fluviatilis, and Stenella cyclimene) were identified as parentic hosts of $A$. typica found in Brazilian waters (Iñiguez, Carvalho, Motta, Pinheiro, \& Vicente, 2011 and S Mattiucci et al., 2002). According to KKP (2014) K. breviceps and P. electra as well as several species identified as Anisakis parentic hosts reportedly also migrated through the waters of East Nusa Tenggara. A. typica has been reported from marine fish around the world such as in Korea, Japan, China, Portugal, Taiwan, Brazil, Maroco, Papua New Guinea and the Mediterranean Sea (X. Q. Zhu et al., 2007; Farjallah et al., 2008; Umehara et al., 2010; and Koinari et al., 2013).

Genetic Characterization of $A$. typical. Isolate $A$. typica after observing its clinical symptoms; a PCR assay was performed to determine the genetic character of $A$. typica from skipjack tuna (Katsuwonus pelamis). The positive amplicon was identified as $A$. typica, carried out DNA purification. After that, sequencing and phylogenetic analysis were carried out. The results of PCR amplification using ITS primers (ITS 1.58S rDNA and ITS 2), showed that the individuals identified were $A$. typica in the 975 bp band (Figure 2).

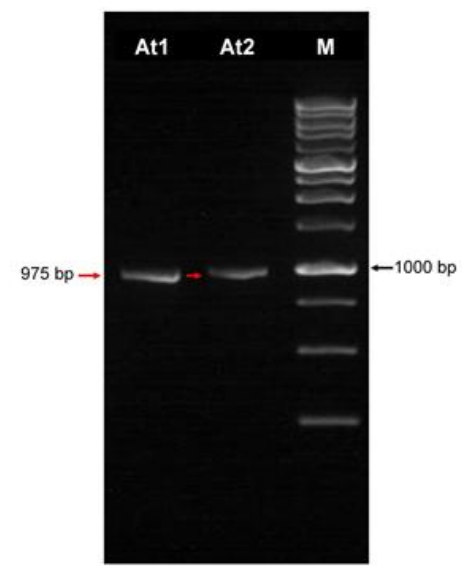

Figure 2 - PCR assay results for A. typica species (At1 and At2 = samples; $M=$ Marker) 
Based on the alignment results in Figure 3, between At1 and At2 isolates against A. typica (Outgroup), showed that At1 and At2 isolates had high homologs. The results of the nucleotide/sequence sequences of At1 and At2 isolates with their isolates showed that there were differences in nucleotide base pairs or mutations in the isolates of A.typica isolates of At1 and At2, which indirectly changed the composition of their amino acids.

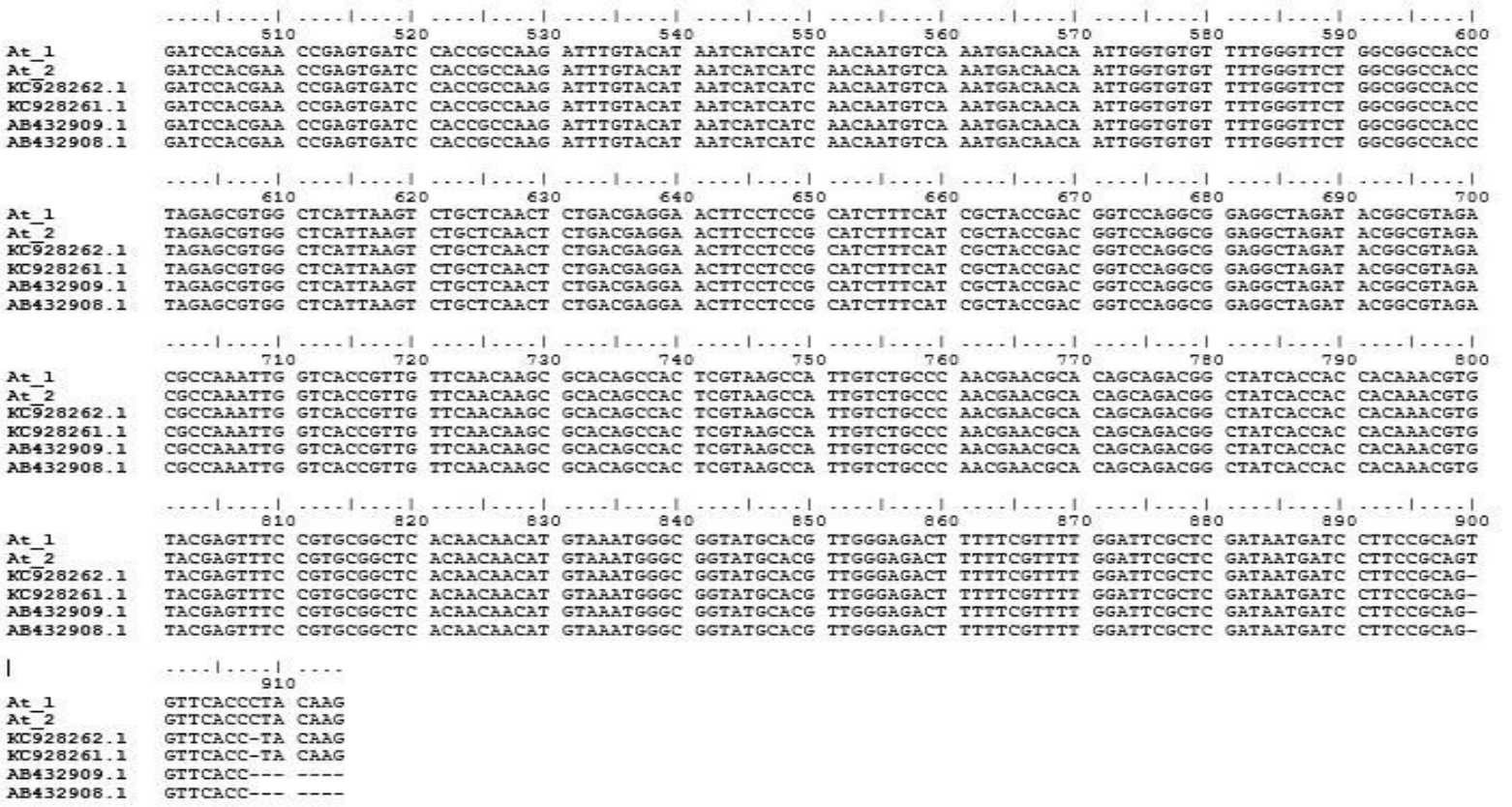

Figure 3 - Alignment Results in between At1 and At2 isolates against A. typica (Outgroup)

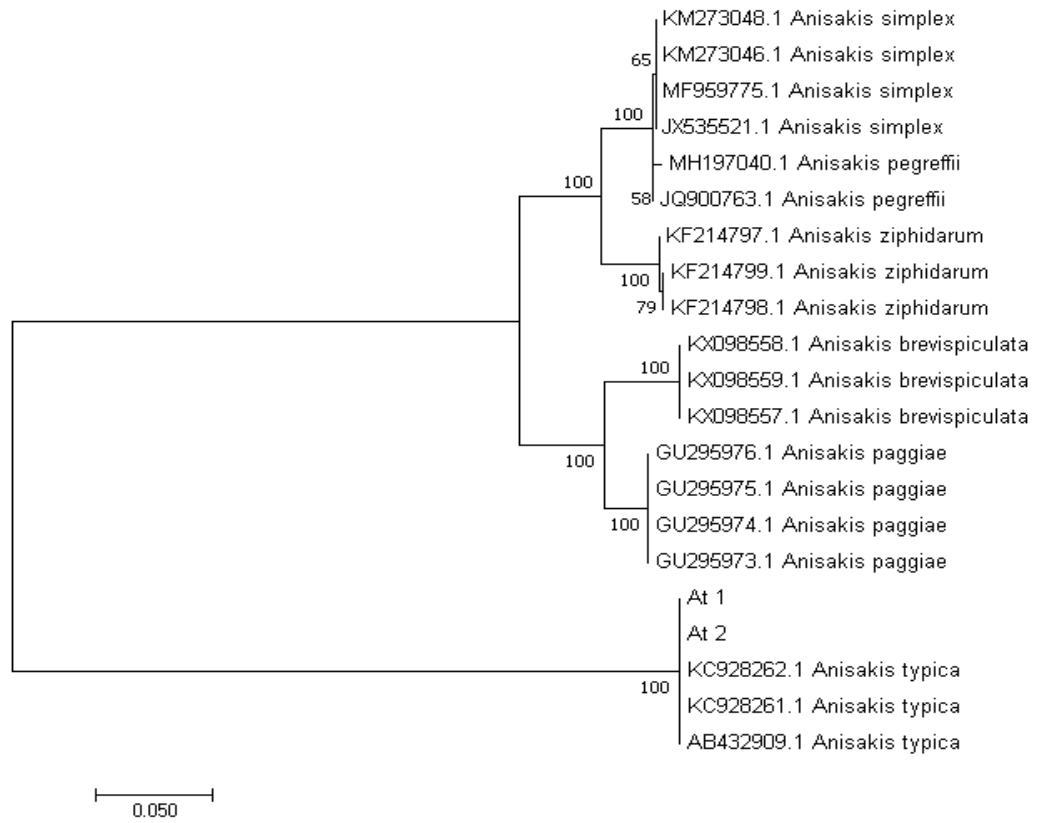

Figure 4 - Phylogenetic trees of At1 and At2 isolates with 19 comparative isolates

Molecular identification results by Palm et al. (2008) and Anshary et al. (2014) found A. typica as the dominant species in the waters of Bali and the Makassar Strait. Both of these waters were adjacent to the waters of East Nusa Tenggara. The results of $A$. typica in these two waters are inseparable from the life pattern of Anisakis nematodes, the distribution of skipjack tuna and the migration patterns of some marine mammals as parent hosts. 
The waters of East Nusa Tenggara were the migration area of 30 species of Cetaceans, especially whales and dolphins. Whales and dolphins migrate from the Pacific Ocean to the Indian Ocean through Indonesian waters, especially through the waters of the Savu Sea, East Nusa Tenggara. The Savu Sea is a deep-sea bounded by the islands of Timor, Rote, Sumba, Flores, Solor, Alor, and Lembata and was reported to have a high diversity of cetaceans (there are 19 species of cetaceans in these waters) (Kahn, JamesKahn, \& Pet, 2000).

\section{CONCLUSION}

The conclusions of this study were the results of morphological and PCR-sequencing of 2 samples observed from Savu sea, showed that the type I Anisakis species isolated from skipjack tuna was A. typica. The results of this study can be used to identify Anisakis spp parasites in Indonesian waters.

\section{ACKNOWLEDGMENTS}

We thank the Ministry of Marine Affairs and Fisheries, Republic of Indonesian and Fish Quarantine and Inspection agency Kupang for research funding (grant No.113/SJ/KP.532/III/2016).

\section{REFERENCES}

1. Anshary, H. (2011). Molecular Identification of Anisakis spp (Nematode: Anisakidae) from Frigate Tuna (Auxis thazard) and Indian Mackerel (Rastrelliger kanagurta) of Makassar Waters. Journal of Fisheries Science, XIII(2), 70-77.

2. Anshary, H., Sriwulan, Freeman, M. A., \& Ogawa, K. (2014). Occurrence and molecular identification of Anisakis Dujardin, 1845 from marine fish in southern Makassar Strait, Indonesia. Korean Journal of Parasitology, 52(1), 9-19. https://doi.org/10.3347/kjp.2014.52.1.9.

3. Cheng, T. C. (1982). Anisakiasis. In J. . Steele (Ed.), CRC Handbook Series in Zoonoses: Vol. II (pp. 37-54). CRC Press.

4. D'Amelio, S., Mathiopoulos, K. D., Santos, C. P., Pugachev, O. N., Webb, S. C., Picanco, M., \& Paggi, L. (2000). Genetic markers in ribosomal DNA for the identification of members of the genus Anisakis (Nematoda: Ascaridoidea) defined by polymerase-chainreaction-based restriction fragment length polymorphism. International Journal for Parasitology, 30(2), 223-226. https://doi.org/10.1016/S0020-7519(99)00178-2.

5. Farjallah, S., Busi, M., Mahjoub, M. O., Slimane, B. Ben, Paggi, L., Said, K., \& D'Amelio, S. (2008). Molecular characterization of larval anisakid nematodes from marine fishes off the Moroccan and Mauritanian coasts. Parasitology International, 57(4), 430-436. https://doi.org/10.1016/j.parint.2008.05.002.

6. Grabda, J. (1991). Marine fish parasitology (E. Grabda, ed.). Poland: Polish Scientific Publishers.

7. Hassan, M. A., Mohamed, A. E.-M. H., \& Osman, H. A. M. (2013). Some studies on Anisakidae larvae in some marine fish species. Researcher, 5(12), 608-614. https://doi.org/10.13243/j.cnki.slxb.2013.05.013

8. Iñiguez, A. M., Carvalho, V. L., Motta, M. R. A., Pinheiro, D. C. S. N., \& Vicente, A. C. P. (2011). Genetic analysis of Anisakis typica (Nematoda: Anisakidae) from cetaceans of the northeast coast of Brazil: New data on its definitive hosts. Veterinary Parasitology, 178(3-4), 293-299. https://doi.org/10.1016/j.vetpar.2011.01.001.

9. Kahn, B., James-Kahn, Y., \& Pet, J. (2000). Komodo National Park cetacean surveys-A rapid ecological assessment of cetacean diversity, distribution and abundance. Indonesian Journal of Coastal and Marine Resources, 3(2), 41-59.

10. Koinari, M., Karl, S., Elliot, A., Ryan, U., \& Lymbery, A. J. (2013). Identification of Anisakis species (Nematoda: Anisakidae) in marine fish hosts from Papua New Guinea. 
Veterinary Parasitology, 193(1-3), 126-133. https://doi.org/10.1016/j.vetpar.2012.12.008.

11. KKP (Ministry of Marine and Fisheries). 2014. Ministry of Marine and Fisheries Decision of Republik Indonesia No.6/KEPMEN-KP/2014. Management planning and zoning of Savu sea national park and surround area in East Nusa Tenggara. 427. 2014-2043.

12. Mattiucci, S, Paggi, L., Nascetti, G., Portes Santos, C., Costa, G., Di Beneditto, A. ., ... Bullini, L. (2002). Genetic markers in the study of Anisakis typica (Diesing, 1860): larval identification and genetic relationships with other species of Anisakis Dujardin, 1845 (Nematoda: Anisakidae). Systematic Parasitology, 51, 159-170.

13. Mattiucci, Simonetta, \& Nascetti, G. (2008). Advances and Trends in the Molecular Systematics of Anisakid Nematodes, with Implications for their Evolutionary Ecology and Host-Parasite Co-evolutionary Processes. In Advances in Parasitology (Vol. 66, pp. 47148). https://doi.org/10.1016/S0065-308X(08)00202-9.

14. Mladineo, I., Šimat, V., Miletić, J., Beck, R., \& Poljak, V. (2012). Molecular identification and population dynamic of Anisakis pegreffii (Nematoda: Anisakidae Dujardin, 1845) isolated from the European anchovy (Engraulis encrasicolus L.) in the Adriatic Sea. International Journal of Food Microbiology, 157(2), 224-229. https://doi.org/10.1016/j.ijfoodmicro.2012.05.005.

15. Nagasawa, K., \& Moravec, F. (1995). Larval Anisakid Nematodes of Japanese Common Squid (Todarodes pacificus) from the Sea of Japan. The Journal of Parasitology, 81(1), 69-75. https://doi.org/10.2307/3284008.

16. Palm, H. W., Damriyasa, I. M., Linda, \& Oka, I. B. M. (2008). Molecular genotyping of Anisakis Dujardin, 1845 (Nematoda: Ascaridoidea: Anisakidae) larvae from marine fish of Balinese and Javanese waters, Indonesia. Helminthologia, 45(1), 3-12. https://doi.org/10.2478/s11687-008-0001-8.

17. Palm, H. W., Theisen, S., Damriyasa, I. M., Kusmintarsih, E. S., Oka, I. B. M., Setyowati, E. A., ... Kleinertz, S. (2017). Anisakis (Nematoda: Ascaridoidea) from Indonesia. Disease of Aquatuc Organism, 123, 141-157.

18. Quiazon, K. M. A., Yoshinaga, T., Santos, M. D., \& Ogawa, K. (2009). Identification of Larval Anisakis spp. (Nematoda: Anisakidae) in Alaska Pollock (Theragra chalcogramma) in Northern Japan Using Morphological and Molecular Markers. Journal of Parasitology, 95(5), 1227-1232. https://doi.org/10.1645/ge-1751.1

19. Sakanari, J. A., \& Mckerrow, J. H. (1989). Anisakiasis. Clinical Microbiology Reviews, 2(3), 278-284.

20. Setyobudi, E., Jeon, C. H., Lee, C. H., Seong, K. B., \& Kim, J. H. (2011). Occurrence and identification of Anisakis spp. (Nematoda: Anisakidae) isolated from chum salmon (Oncorhynchus keta) in Korea. Parasitology Research, 108(3), 585-592. https://doi.org/10.1007/s00436-010-2101-x.

21. Setyobudi, E., Rohmah, I., Fauziana Syarifah, R., Ramatia, L., Murwantoko, M., \& Wahyu Kartika Sari, D. (2019). Presence of Anisakis nematode larvae in Indian mackerel (Rastrelliger spp.) along the Indian Ocean southern coast of East Java, Indonesia. Biodiversitas Journal of Biological Diversity, 20(1), 313-319. https://doi.org/10.13057/biodiv/d200136.

22. Umehara, A., Kawakami, Y., Ooi, H. K., Uchida, A., Ohmae, H., \& Sugiyama, H. (2010). Molecular identification of Anisakis type I larvae isolated from hairtail fish off the coasts of Taiwan and Japan. International Journal of Food Microbiology, 143(3), 161-165. https://doi.org/10.1016/j.ijfoodmicro.2010.08.011.

23. Yoshinaga, T., Kinami, R., Hall, K. A., \& Ogawa, K. (2006). A Preliminary Study on the Infection of Anisakid Larvae in Juvenile Greater Amberjack Seriola dumerili Imported from China to Japan as Mariculture Seedlings. Fish Pathology, 41(3), 123-126. https://doi.org/10.3147/jsfp.41.123.

24. Zhang, L., Hu, M., Shamsi, S., Beveridge, I., Li, H., Xu, Z., ... Gasser, R. B. (2007). The specific identification of anisakid larvae from fishes from the Yellow Sea, China, using mutation scanning-coupled sequence analysis of nuclear ribosomal DNA. Molecular and Cellular Probes, 21(5-6), 386-390. https://doi.org/10.1016/j.mcp.2007.05.004.

25. Zhu, X., Gasser, R. B., Podolska, M., \& Chilton, N. B. (1998). Characterisation of anisakid 
nematodes with zoonotic potential by nuclear ribosomal DNA sequences. International Journal for Parasitology, 28(12), 1911-1921. https://doi.org/10.1016/S00207519(98)00150-7.

26. Zhu, X. Q., D'amelio, S., Palm, H. W., Paggi, L., George-Nascimento, M., \& Gasser, R. B. (2002). SSCP-based identification of members within the Pseudoterranova decipiens complex (Nematoda: Ascaridoidea: Anisakidae) using genetic markers in the internal transcribed spacers of ribosomal DNA. Parasitology, 124(6), 615-623. https://doi.org/10.1017/s0031182002001579.

27. Zhu, X. Q., Podolska, M., Liu, J. S., Yu, H. Q., Chen, H. H., Lin, Z. X., ... Lin, R. Q. (2007). Identification of anisakid nematodes with zoonotic potential from Europe and China by single-strand conformation polymorphism analysis of nuclear ribosomal DNA. Parasitology Research, 101(6), 1703-1707. https://doi.org/10.1007/s00436-007-0699-0. 